University of Wollongong

Research Online

Faculty of Education - Papers (Archive)

Faculty of Arts, Social Sciences \& Humanities

$19-6-2012$

\title{
Neither good nor useful: Looking ad vivum in children's assessments of fat and healthy bodies
}

Valerie Harwood

University of Wollongong, vharwood@uow.edu.au

Follow this and additional works at: https://ro.uow.edu.au/edupapers

Part of the Education Commons

\section{Recommended Citation}

Harwood, Valerie: Neither good nor useful: Looking ad vivum in children's assessments of fat and healthy bodies 2012.

https://ro.uow.edu.au/edupapers/1210

Research Online is the open access institutional repository for the University of Wollongong. For further information contact the UOW Library: research-pubs@uow.edu.au 


\title{
Neither good nor useful: Looking ad vivum in children's assessments of fat and healthy bodies
}

\author{
Valerie Harwood* \\ Faculty of Education, University of Wollongong, Wollongong, Australia
}

\begin{abstract}
Fat bodies are not, fait accompli, bad. Yet in our international research we found overwhelmingly that fat functioned as a marker to indicate health or lack of health. A body with fat was simply and conclusively unhealthy. This paper reports on how this unbalanced view of fat was tied to assessments of healthy bodies that were achieved by the act of looking. Despite the efforts of health education in each of the three countries in our study, children and young people cited the act of looking at bodies to assess health and when they did they arrived at the conclusion that fat on bodies is unmistakably bad. The paper uses a Foucauldian analysis of medical perception together with material from Conrad Gessner's sixteenth century Historia Animalium to outline how the children in our study placed great reliance on information about fat to make almost exclusively visual assessments of health. The paper makes the case that, despite a great deal of health education in schools, these judgments reveal a tendency for children to make incorrect assessments of health.
\end{abstract}

Keywords: fat, obesity, children, visual, children's health assessments, public health, Conrad Gessner, ad vivum

\section{Introduction}

Interviewer: How do you know what a healthy body is?

Student: For me a healthy body is someone who doesn't have much weight on them, say maybe an extra five kilograms on them of actual fat. I'm not really quite sure of the rest. (Interview with male student, aged 16 years, Australia) ${ }^{1}$

In the interview extract above, fat is considered a possibility in a healthy body. As I will go on to outline, this comment on fat and health was one of the rare statements that emerged from our research with children and young people in Australia, New Zealand and England. Overwhelmingly the data revealed how fat functioned as a marker that served to indicate health or lack of health: absence of fat on bodies meant health and its presence almost always meant lack of health. In sum, a body with fat

Faculty of Education, University of Wollongong, Wollongong, Australia. Email: vharwood@uow.edu.au 
was simply and conclusively unhealthy. By contrast, our interview participants granted greater leeway to fat that is consumed. Consumed fat could be permissible and was not pejoratively bad; that depended on quantities and type, with eating too much fat by people perceived to be fat the fundamental issue. This unbalanced view of fat was tied to assessments of healthy bodies that were achieved by the act of looking. Despite the efforts of health education in each of the three countries in our study, children and young people cited the act of looking at bodies to assess health, and when they did they arrived at the conclusion that fat on bodies is unmistakably bad.

Fat on bodies is not, fait accompli, bad. There are anomalies with fat such as the problem of lean people being at greater risk of atherothrombotic diseases (Andreotti, Rio, \& Lavorgna, 2009). Such instances point to the inaccuracy of typecasting fat as always bad and question painting it as of no use or value. Recent research on brown adipose tissue (BAT) adds strength to the argument for a balanced view of fat on bodies. BAT is referred to as the 'good fat', with white adipose tissue the bad fat (Rutkowski, Davis, \& Schere, 2009; Tan, Manchester, Fuentes-Broto, Parades \& Reiter, 2010). This good fat has qualities that include burning energy,

\footnotetext{
Cells in brown fat, considered a 'good fat' for its energy-burning qualities, contain many little droplets of lipid, each with its own power source, which enables heat generation. Babies have ample stores of brown fat at birth as a defense against the cold, but it mostly disappears, as adults have very little of this calorie-burning tissue. (Johns Hopkins Medical Institutions, 2011, May 5)
}

This is a useful counter to the bad and non-useful claims, even taking into account the issue that dichotomy between the good and the bad may prompt further health moralising (Gracia-Arnaiz, 2010; Le Besco, 2010). This is suggestive of the need for a nuanced understanding of fat and how fat is connected with health, but is far from how children and young people understand and recognise fat on bodies.

In our study the children's and young people's reliance on looking for fat on bodies to assess health pointed to two important problems in their understandings of health. The first is the considerable lack of knowledge about healthy bodies. Our participants seldom described what might occur inside bodies that could contribute to a healthy body. Comments that drew on physiological change within a body were atypical, 'if you exercise more your blood vessels keep their shape and if you eat too much junk food they can get clogged up ... and you get heart attacks and that' (Male, 10 years, New Zealand). Repeatedly, fat was discussed as neither good nor useful and the way this was determined was via looking. This overriding reliance on looking as a means to assess health is the second problem, insofar as this is the predominant way that they produced their understandings of healthy bodies.

The purpose of this paper is to consider these two problems in order better understand how the children and young people made health assessments. Drawing on Foucault's (1994) analysis of medical perception, my contention is that the children in our study used a particular form of looking to make their assessments and that this form of looking was treated with special emphasis that achieved authority. Interestingly - and by way of building a useful analytic juxtaposition - the person who was the first to discover brown adipose tissue is also famous for introducing to Natural History extensive use of naturalistic pictorial representations of animals (Ashworth, 1996). In the sixteenth century the famous natural historian Conrad Gessner marked out the authenticity of his pictures by including the descriptor 'ad vivum' (from life) (Panese, 2005). ${ }^{2}$ This descriptor served to convey how 
representations were achieved and simultaneously assert their veracity. In this paper I draw on this work from the Renaissance to examine the children and young people's assessments of health. This comparison creates an opportunity to examine how children and young people could employ looking to definitively assess health. I thus use Gessner's work in the Foucauldian sense to shed light on contemporary practices of looking and how these portray truths about fat and healthy bodies. My intention is to draw on a style from Foucault's $(1994,2006)$ investigations of medicine and psychiatry as well as to take account of Sander Gilman's (2011) cogent point concerning the study of images in the history of medicine. As Gilman observes, it is important for historical work on images to 'come much closer to their underlying epistemic value in any given system' (p. 73). A Foucauldian approach with its attention to historical sources can highlight particularities of truths, and in so doing, bring attention to the epistemic values present in children's decisions about health (Harwood, 2011).

The paper begins with discussion of how the children and young people used 'looking' to assess health and what it was that they looked at to make these assessments. This leads to my discussion of Conrad Gessner's use of 'ad vivum'. In this section I refer to historical images from Gessner's sixteenth century compendium Historia Animalium as well as his discovery of brown adipose tissue to build my analysis of the children's mode of looking. Lastly, working with the juxtaposition of Gessner's ad vivum, I discuss the children's understandings of health and their idiosyncratic looking ad vivum. The ad vivum methods Gessner used to gather information to represent creatures provides a point from which to stretch back to consider a different way of looking, employed more than four centuries ago. As I hope to convey, considering this Renaissance work alongside findings from our study - as well as accepted contemporary scientific practices - can point to the problematic knowledge produced via children's and young people's contemporary way of looking ad vivum at fat.

\section{Assessing health by looking at fat}

One of the notable findings from our recent international study was the large degree to which children and young people reported that they 'assessed by looking'. The fieldwork reported in this paper is from an international project funded by the Australian Research Council and the UK Economic and Social Research Council. This project investigated how prevailing attitudes and practices relating to 'obesity', food, physical activity, and health are embedded in school policy and in the curriculum, actions and attitudes of teachers and how this affects teachers and students in the ways they understood health, their bodies, and their selves. ${ }^{3}$ Fieldwork for the project was conducted with nine primary schools and six secondary schools across Australia, England and New Zealand, and included State schools and Independent Schools from a mix of geographic and socio-economic areas. ${ }^{4}$ Data collected totalled 2636 surveys (Australia: 900; England: 1176; New Zealand: 560), 212 interviews (Australia: 82; England: 90; New Zealand: 40) and detailed field observations. $^{5}$

To make assessments of health, the children and young people relied on looking at bodies. The Australian and New Zealand surveys asked the question, 'How do you know if a person is healthy?' with the responses conveying that children and young people were confident in assessing health, and could achieve this via looking at how 
others looked. In the cohort of 15 to 16 year olds at one Australian secondary school only one student stated that you need to 'ask them' and only one said, 'I don't know'. The children simply had the conviction that there was no need to ask questions in order to test for health. In the English surveys a minority of 15 out of 1176 responses described assessing health as difficult or not possible. This prominence of looking is surprising given the availability in schools of devices such as scales as well as the function of these in providing scientifically authorised assessments (Cambrosio, Keating, Schlich, \& Weisz, 2009; Rabinow, 1992). The surveys in England revealed ' $38 \%$ of students had been weighed at school' (Rich et al., 2009, p. 16), a figure that suggests the children might possibly more often select weighing for gauging health. This, however, was not the case with their health assessments being based on how a person looked.

Assessments based on looking used three key categories: shape, movement and intake, an identification process that is explicit in the interview excerpt below:

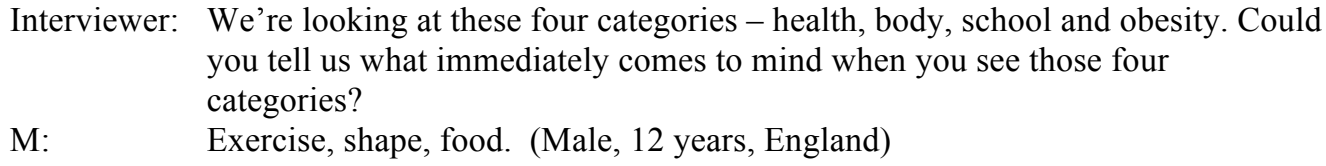

Across the different sites we repeatedly found participant responses that relied on looking to assess health, with patterns consistently based on categories of shape, movement and intake. The most frequent responses that defined health in each of these categories are summarised in Table 1. When such responses linked health and obesity, they relied assessment of fat, and, as I go on to outline, these were based on shape, movement and intake.

\begin{tabular}{|l|l|l|l|}
\hline & SHAPE & MOVEMENT & INTAKE \\
\hline HEALTHY & Non-fatness & $\begin{array}{l}\text { Exercise, physical } \\
\text { activity }\end{array}$ & $\begin{array}{l}\text { Doesn't affect } \\
\text { shape }\end{array}$ \\
\hline NON-HEALTHY & Fatness & Lack of movement & Affects shape \\
\hline
\end{tabular}

Table 1: Assessing health by looking: categories and criteria

\section{Shape}

Shape was an important means for assessing health. In the English interviews children were shown different pictures of people and asked whom they may or may not like to look like. The responses connected shape with health, such as 'her dress doesn't fit her; she's big and that's so tight for her' (Female, 11 years, England). When shown a picture of a man measuring his (large) waist, children commented that 'he don't look that healthy' and explained this was because 'the measure fits around his whole belly' (Female, 11 years, England). The New Zealand and Australian surveys included the question, 'Do you think a person's shape or size has anything to do with their health?' Of the 148 primary students who responded, $68 \%$ of students described 'shape' as related to health. The children demarcated shapes in terms of two options: fatness or thinness, with fatness connected to health far more than thinness or skinniness. Height counted little as a shape, with few mentioning tall or short. While there were comments about the size of stomachs or evidence of muscles as indicators of health, 
large shapes were the predominant indicator of fatness. Health could thus be determined if fatness were absent (and to a much lesser degree, thinness). In one of the Australian secondary schools, $51 \%$ of the male students aged 13 to 14 described health in terms of 'the way they look', with this appearance being judged in terms of body shape, as well as weight and fat.

Attention to shape as an indicator was likewise evident in responses to the Australian and New Zealand survey question, 'have you ever thought you needed to get thinner?' Responses to this question were influenced by gender and by age, with 'yes' responses varying between older and younger boys. In the primary/intermediate Australian and New Zealand schools, $46 \%$ of girls answered 'yes', compared to $20 \%$ of boys (153 responses). For the older students this percentage increased, with 58\% of the female secondary school students and $34 \%$ of the male students responding 'yes'. When asked 'how health is assessed', the younger students tended to focus on body shape, weight, fatness and skinniness, and older students included indicators such as body image and appearance. Older secondary students' responses suggested that they were concerned to be thin and at the same time aware of their appearance to those around them. In this regard it is not the case that shape decreased as a measure of health; rather other indicators were added to and consequently extended on an existing repertoire of shapes for gauging health. Indicators such as body image could thus be linked to a barometer of shapes that had been established at an earlier age.

'Tone' was another shape that was held to be important. As with other shapes, tone equalled health and could be assessed easily by visual inspection. Two female students discussed this in one of the interviews, explaining that,

Being toned is quite good, it looks quite good and it looks like you eat healthily and it looks like you are happy but it just look like they feel more comfortable with who you are. I associate being thin with not being comfortable with who you are and really insecure. (Female, 16 years, England).

Students related fatness and obesity to putting individuals at risk of illness, as well as using the terms alongside one another. One Australian secondary school student remarked, 'Health can be anything as long as you are not actually sick or unhealthy like obese or anything' (Male, 13 years, Australia). These perceptions of shape were not necessarily used in isolation and would often be linked with important evidence amassed from observation of movement and intake. In practice this meant that children could look for health by detecting the relationship that they perceived between the presence or absence of fat and movement.

\section{Movement}

Health was also assessed through movement, which, like shape, was tied to fatness or obesity. Results from three of the questions in the English survey reveal the importance placed on movement for gauging health. ${ }^{6}$ In these surveys respondents had the opportunity to select or record more than one option. The frequency of responses provides a means to compare across the choices, such as between diet, wellbeing or exercise. In the question about 'what being healthy means' students were asked to write their response (they could provide more than one). Movement (exercise or physical ability) was the most frequent choice, with a frequency of 988 responses and intake rated second, with a frequency of 886 responses. Shape (the body) and wellbeing both rated third with 356 responses. Other interpretations scored significantly lower: positive self-perception, 44 responses; social, 27 responses; 
mental ability, 45 responses; and lifestyle, 70 responses. In the survey question that asked about 'the most important things that someone can do to stay healthy', diet rated higher than exercise, with diet receiving $1279^{7}$ responses and exercise 981 responses. One of the survey questions specifically asked students about how they gauge health: 'I can tell a person is healthy because ...'. For this question, the body had the highest frequency with 880 responses compared to movement, which had 591 responses. Intake had 255 responses, which was almost equaled by wellbeing that had 253 responses. In the English survey only 15 responses indicated that it was not possible to tell if a person is healthy, and a lack of bullying (no one makes fun of you) had only one response. These survey results suggest the extent to which children and young people rely on movement as well as body shape and intake as indicators of health.

Lack of movement meant lack of health, and was again linked to fat and obesity. One method of assessing health, therefore, was to look for movement. As one child explained, 'You look at them kind of they might be kind of big, like you can tell cause they might not be able to run far' (Female, 11 years, New Zealand). These children also described how such unhealthy individuals become,

Puffed and everything, and that sometimes their face and like their eyes are kind of all droopy if they've been smoking their teeth can be and their legs are fat. [Laughs] (Female, 10 years, New Zealand)

Another young person explicitly connected movement with weight, stating health could be gauged by 'the person's weight, reaction, if they're tired in class or if they are failing school or fitness' (Student, 14 years, Australia).

The relationship between fatness and movement meant that children could quickly assess health in terms of fatness and conclude the remedy is to exercise. This line of thought is exemplified in the following quote, where a young person describes her reason for avoiding the television show The Biggest Loser,

\footnotetext{
Well, I don't really watch The Biggest Loser or anything because I know if you see the people and then you compare yourself to them and you're like I'm as fat as them or something then you go out and even if you're not that fat you might exercise more even if you don't need to. (Female, 13 years, Australia)
}

This description provides a good example of the way sources from contemporary visual culture are used by children and young people to gauge not only health, but to assess themselves.

\section{Intake - The end of Epicureanism?}

Enjoyment of food was seldom mentioned by the children and young people. Rather, food was discussed in terms of its capacity for outcomes such as affecting shape or determining energy or in relation to types and quantities of food consumed. The results described above show how in the English survey intake was rated second to movement for defining 'what healthy means'. As a key site for food, the school canteen was frequently mentioned with discussion focusing on selling the correct types of food. This reflects the emphasis schools place on the canteen controlling the types of foods consumed. Student comments picked up on this emphasis with students using words such as 'force' to explain how eating is moderated in their school, 'they do try and force eating right with the canteen and stuff' (Male, 16 years, Australia). 
Children also described how they or others would watch the content and quantity of intake. Observation and vigilance could be acute, as evidenced in this description of a child's endeavours to avoid surveillance,

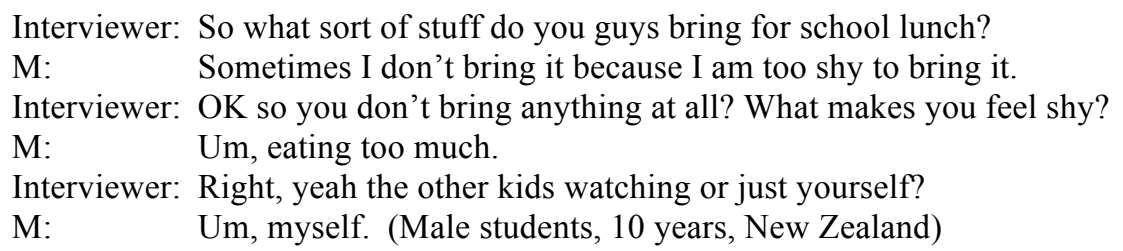

Children and young people rarely described how they ate, whether they shared food or described tasty or delicious food. This focus echoes Klein's (2010) observation about the American relationship to food, where a focus on science is at odds with Epicurean ideals. Klein explains that 'health for the Epicurean is more a matter of art than of science, more an aesthetic than a biological question' (p. 20). The children's and young people's views were far removed from concerns with food as art or aesthetics. Food was almost always linked with an understanding of the science of food concerned with health, fat and obesity.

Attentiveness to shape, as well as movement and intake patterns could also be used to detect mental problems. An Australian Year 11 student applies this connective logic to explain how he assessed a person's mental state,

\footnotetext{
You think you are healthy, physical appearance I guess. Usually it depends on attributes as to how healthy a person could be. A healthy body is you can talk about their mental state. If they don't look too stable then you would question that a little. Ask questions mainly, just ask, like just have a look, sit back and watch them to see what they are like ... you look for physical, see how they cope, just walking around and how active they are through the day.

(Male students, 16 years, Australia)
}

With fatness, thinness and tone so intricately tied to gauging health, it is not surprising that obesity was wielded as a measure of pathology or sickness. This again points to how health (even mental health) is considered to be assessable via the procedure of 'looking'. To explain how this process of looking can be understood I begin by turning to consider the ad vivum of Conrad Gessner, the Renaisssance natural historian who discovered brown adipose tissue.

\section{Ad vivum}

... nec pinguitudo, nec caro ... [neither fat nor flesh]. (Gessner, 1551, p. 842)

Brown adipose tissue (BAT), 'the good fat' was discovered by Conrad Gessner, who noted it was nec pinguitudo, nec caro [neither fat nor flesh] (Gessner, 1551, p. 842). This discovery was made in a somewhat similar way to present day scientific procedures, via dissection and direct observation of the alpine marmot (Marmota marmota). ${ }^{8}$ The illustration of the marmot and the surrounding text (Figure 1) is taken from Gessner's Historia Animalium. Similar to all of the entries, this contains a picture and extensive textual references that span numerous pages. These entries include details ranging the names of the animals, regions inhabited, appearances, sounds, diets as well as 'fables and folklore' (Ashworth, 1996, p. 19). 


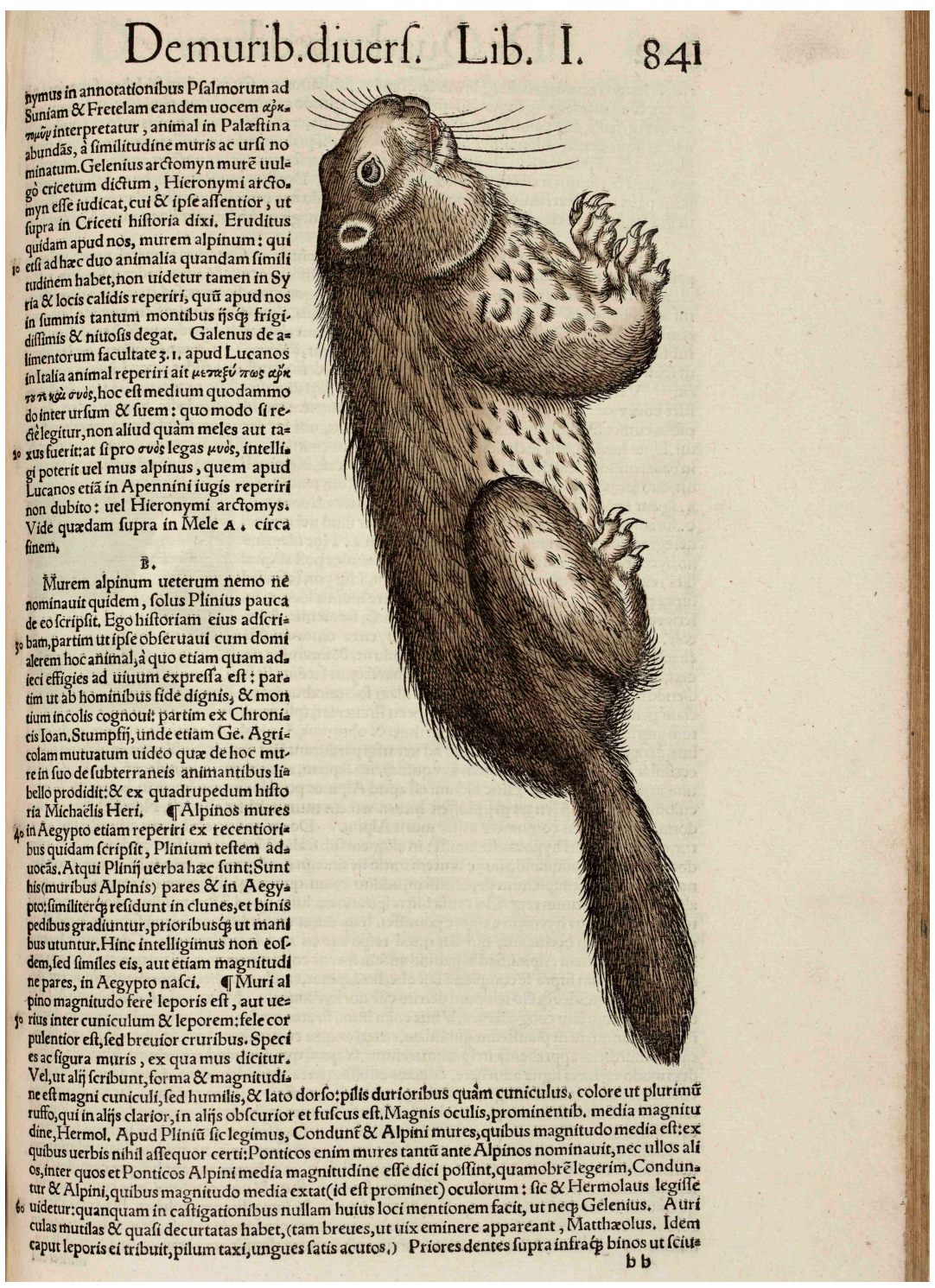

Figure 1. Marmot, Gesner (1551) Historia animalium p. 841

Cambridge University Library, N.1.19. Reproduced by kind permission of the Syndics of Cambridge University Library ${ }^{9}$

Given that dissection and direct observation were used to discover the substance that Conrad described as 'neither fat nor flesh' (later known as BAT), it would appear logical to assume that this was the mainstay of Gessner's method. This assumption however overlooks the varied procedures Gessner employed to gather information ad vivum (Kusukawa, 2010). 'Ad vivum' translates as 'from life' (Speake, 1999), which for Gessner did not stipulate recording from direct contact with the creature itself. ${ }^{10}$ From this perspective ad vivum meant 'either having them drawn himself or accepting from trustworthy friends pictures similarly drawn' (Kusukawa, 2010, p. 307), with information that supplied these illustrations coming from sources that included 'artists, broadsides, books, and manuscripts' (p. 307). This marks a substantial difference between the methods used to collect and represent information in the Historia Animalium and those used in twenty-first century life science.

At first glance Historia Animalium is startlingly unusual. Illustrations of mythic, domesticated, and exotic creatures are placed next to one another in an impressively 
large and detailed catalogue (see Figs. 2-4). The wide variety of sources used to produce depictions of animals in the Historia, sources that, while cited as ad vivum, did not depend on the manner of observation integral to contemporary life sciences. Two apposite examples are the unicorn and sea monster (Figure 3, Figure 4), both of which were derived from reliable sources and based on Gessner's extensive research into the knowledge of the animals of his day.
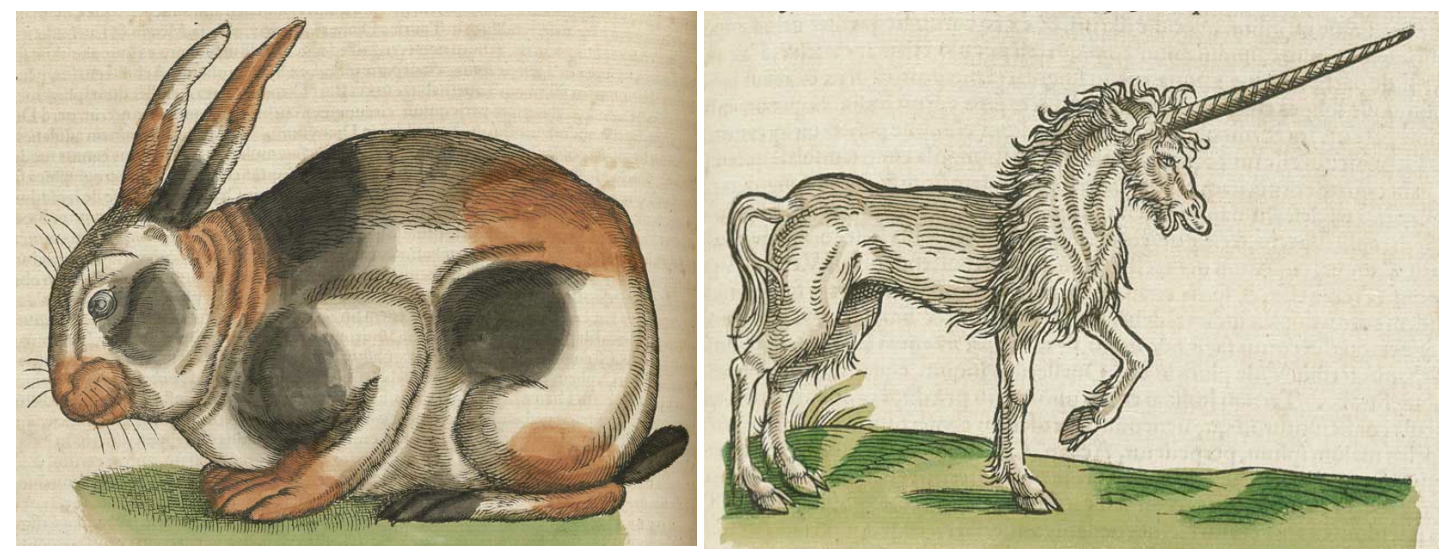

Figure 2. Rabbit, Gessner, Historia Animalium, I p. 394.

Courtesy of the US National Library of Medicine.

Figure 3. Unicorn, Gessner, Historia Animalium, I, p. 781.

Courtesy of the US National Library of Medicine.

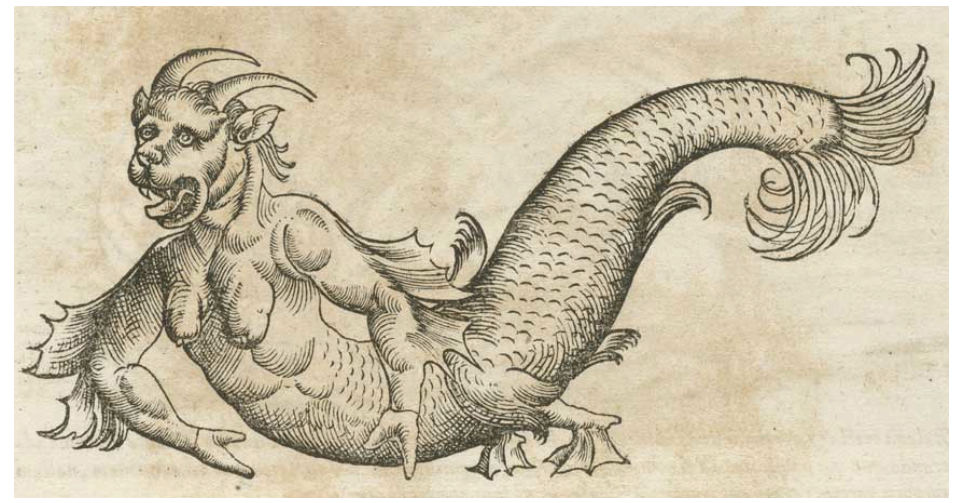

Figure 4. Sea Monster, Gessner, Historia Animalium, IV, p. 175.

Courtesy of the US National Library of Medicine.

The Historia Animalium has five-volumes ${ }^{11}$ and contains over 4,500 pages and is regarded one of the first compendiums of its kind. ${ }^{12}$ While the books are extraordinary in size and content, it is arguably the beauty of the illustrations that has made them especially famous. In this compendium Gessner endeavoured to compile every creature known at the time, seeking to 'report every little thing said about any animal' (Pinon, 2005, p. 249). Each of these volumes was designed as a 'dictionarium' where 'such a presentation is easily followed and renders it possible for the reader to learn 
all that he requires of an animal with minimum of trouble' (Gessner, cited in Fischer, 1966, p. 278). To accomplish this monumental task, Gessner drew on reports made from his own experience of animals and the reports of others (Pinon, 2005) and '[r]arely was direct experience or observation the sole criterion for including an animal, while the existence of a textual description was' (Kusukawa, 2010, p. 306). The ad vivum of Gessner could be characterized as one where the assertion of authority of direct observation was predicated on the author's direct experience, with direct experience being inclusive of processes such as textual description as well as seeing the animal itself. In this sense the ad vivum has a particular meaning for the time of Gessner; one that is achieved through a process of observation from life that can include his own experience (such as with the marmot and the discovery of BAT), as well as the direct experience of textual references of creatures such as the unicorn. For this reason the unicorn, the sea monster and the satyr can be true for Gessner without his ever having to have directly observed them.

The illustrations in the Historia Animalium are accessible and striking but the text is not, being only available to readers of Latin. While no exact translation of the original work exists, ${ }^{13}$ accounts of specific entries offer a glimpse of the textual content. Ashworth (1996) for example draws on a translation of the entry on the fox to outline the many details provided. As indicated earlier, these range from physical descriptions to the inclusion of 'folktales and myths'. Reference to the latter could be interpreted by contemporary standards as a sign of the unreliability of the Historia Animalium. On this premise,

... one might choose to believe, as many commentators have, that Gessner was simply a lousy natural historian; that for all his humanistic fervour he patently lacked the common sense to discriminate between fact and fiction. (Ashworth, 1996, p. 20)

Against this appraisal, Ashworth (1996) suggests that 'Gessner used every available thread because he was trying to weave the richest tapestry possible' (p. 20).

While the unusual collections of animal representations distinguish the Historia Animalium from contemporary scientific works, I suggest that the difference is instructive for analysing how the children and young people in our study made truthful assessments of fat and health. To ask, for example, how it was possible for representations of unicorns, sea monsters, and rabbits to be considered truthful, light can be shed on both the way in which knowledge was construed at that moment and in that culture. This question also requires consideration of how Gessner secured descriptions of these creatures, and why, at this time, these descriptions were acceptable.

This is not to put forward the claim that the young participants in our study replicated the methods used by Gessner. Rather, it is to consider Gessner's work and approach as a means to gain a better understanding of the way in which the participants in our study looked at bodies to assert a kind of ad vivum authority which they employed to make conclusions about fat and health.

Our respondents did not just provide detailed accounts that wove, as Gessner did and to paraphrase Ashworth (1996, p. 20), 'the richest tapestry possible'. Their tapestries were meager by comparison. While this may be so, the tapestries that were described reveal a good deal about the ways our participants told truths about health and fat and the means by which this truth was arrived at, namely 'looking'. This I contend is useful for understanding how children and young people use looking to make their truths about fat, health and healthy bodies. 


\section{Looking ad vivum to assess health}

Looking ad vivum at information on shape, movement and intake was the way students assessed health. Many of their responses include the word 'look', with reports that they know if a person is healthy by 'looking at them' by 'how they look', 'the way they look' or that they could assess health 'by looking at their figure and seeing what they eat' (Year 10 student, Australia). When juxtaposed with Gessner's ad vivum it can be argued that the labels 'looked' or 'looking' provided substantial authority for the children's and young people's assessments. The phrase 'I looked at them' functioned as a statement of authority (what I am calling looking ad vivum).

Taking this juxtaposition further it is evident that Gessner searched out many sources to produce accounts of many animals. Here the children differ significantly, for what cannot be found in their accounts is a breadth of perspective. There are simply glaring omissions in their summaries of what makes a healthy body and how fat is not good and not useful. For instance, while they may express moderation in relation to consumption, their accounts vary greatly between what can go into their mouths and that permissible on a healthy body. Unlike Gessner, their assessments of health are brief and formulated on limited information. Compared to Gessner's numerous canvassing of sources, sparseness is the most notable feature of the accounts that we collected.

The children and young people's accounts and ways of looking at health and fat also differ from a contemporary scientific gaze. Most noteworthy, they concentrate on only on exteriors. This is not the case in the twenty-first century representation of BAT (Figure 5).

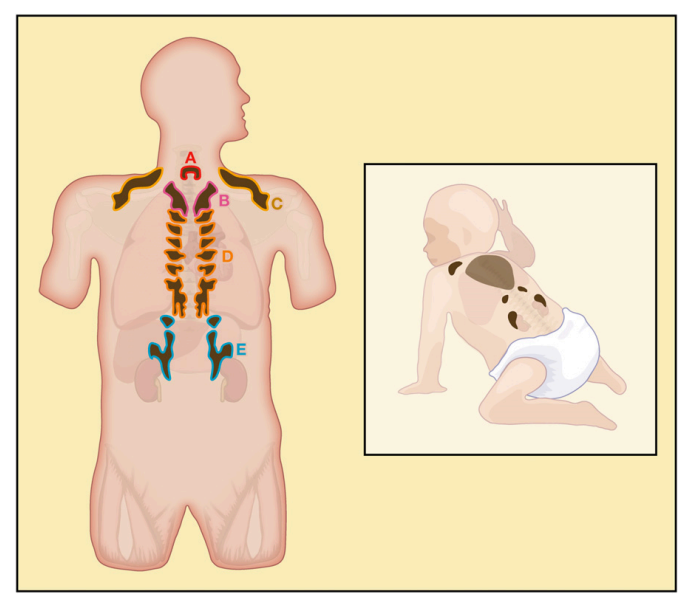

Figure 5. Location of hBAT in Adults and Infants, (Enerbäck, 2010). Reprinted from Cell Metabolism, 11/4, Enerbäck Human brown adipose tissue 248-252, Copyright (2010), with permission from Elsevier.

The illustration 'hBAT in Adults and Infants' (Figure 5) portrays a gaze that reaches to interiors and pinpoints the anatomical location of hBAT. Describing the capacity of the clinical gaze to penetrate its object, Foucault's point is not that it saw its object with more precision, but rather it was the effect the gaze had on what it saw. The clinical gaze in this sense is 'bringing them nothing more than its own light' (Foucault, 1994, p. xiii). This meant that 'the residence of truth in the dark centre of things is linked, paradoxically, to this sovereign power of the empirical gaze that turns 
their darkness into light' (Foucault, 1994, p. xiii). The hBAT illustration bears the hallmarks of such a scientific clinical gaze and also functions to deliver the message of accuracy. This is because diagrams such as these emphasise the precision secured via visual inspection and as such, add to an already powerful visual culture of the science of health (Gilman, 2011).

This depiction differs quite markedly from both the exterior gaze produced by the children and young people's looking ad vivum. It is also quite different from the report of the marmot in Historia Animalium, where illustrations were integral for chronicling creatures but the location of BAT (neither fat nor flesh) within the marmot remained unseen. ${ }^{14}$ These differences underscore the degree to which looking ad vivum by the children and young people is out of step with the contemporary health knowledge practices. Unlike the scientific drawings commonly made available in education or in the media (Bender \& Marinnan, 2010), rarely did looking encompass description of what might lie below the surface - or suggest that healthy bodies are connected to what is happening inside. That this ad vivum looking of children and young people occurs so strongly in a culture replete with diagrams that probe below surfaces of things to reveal hidden structures points to significant issues with the perception of bodies. This I suggest is a finding that raises questions concerning the outcome of health initiatives that target obesity. The reliance on looking ad vivum thus reveals a good deal about the emphasis that imperatives of health and obesity have on the cultural worlds of students.

Although taking from life to assess health meant accessing the range of sources that offer information about health and obesity, it is important to take a cautionary approach to assuming that students devour such messages uncritically. As Burrows (2010) argues in her discussion of eating and exercise programs in New Zealand, it is not necessarily the case that children will follow messages as they are conveyed or intended. Indeed, they can at times disrupt health imperatives and ask questions, actions which "elucidate children's capacity to modify the "truths" to which they are exposed and to disrupt taken for-granted assumptions about what constitutes good or healthy food' (Burrows, 2010, p. 246).

If children make modifications and disruptions to health messages about food, the question needs to be asked, what about how they assess health and the notion of the healthy body? Unlike the above, the assessments by the children in our study modified truths insofar as they were inaccurate, taking interpreting health messages to an extreme. To offer an assessment where fat could be useful and not all bad would demand a different engagement with health messages that would require momentous shifts in looking ad vivum at shape, movement and intake. It may even be the case that this emphasis on looking is the product of health messages.

Capacity for disruption might also need to take into account the effect of lay epidemiology. Following Frankel, Davison, and Smith's (1991) line of argument, the emphasis on shape, movement and intake could be linked to perceptions of candidacy for fatness and obesity. ${ }^{15}$ This observation lends insight into the difficulties of conceiving of health differently, especially the degree of influence that the visual has in the meaning making of health (Gilman, 2011).

The conclusion that fat is neither good nor useful, together with the reliance on looking as prima facie method means that we need to pay attention to the influence of visual interpretations in children's and young people's assessments of health. In the interview excerpt below, visual interpretations of shape, movement and intake are brought together by students to make assessments, 
C That is the first thing that comes to my mind when I think of it. You hear Australia is now the fattest nation in the world.

I think it's definitely from the media like we hear about it. So obviously that is how we heard about it. I guess you see it, like you see overweight people and stuff and you think it is getting more of an issue like with little kids. (Female student, 14 years, Australia)

In this explanation the information came from both the media and 'seeing it' for themselves. The young women then provide a detailed example,

S You see a little kid at the beach with their parents and they are feeding them hot chips and they are already overweight and you are like what is this doing for this child, like their self-esteem is going to be low when they're older and they are going to learn these unhealthy habits. So you obviously see it and you hear about it and like I think it is just all around us all the time. (Female student, 14 years, Australia)

This description does not stop at providing an assessment of intake and shape in a child, but also speculates about the child's unhealthy future. Using lay epidemiology (Davison et al., 1991) this 'little kid' could be viewed as a prime candidate for illhealth as opposed to a child who is assessed as non-fat and who does eat 'hot chips'. The latter child would not be seen as a having the same candidacy for ill health. In this way health perceptions premised on the visual inspection for fatness produce inaccurate health assessments.

The concept of ad vivum can be used to capture these idiosyncratic ways that children and young people use specific visual cues to authoritatively assess healthy bodies. Over and over what stands out is the veracity achieved by looking at the source, which are shapes, movements, intakes. This reference to the process of looking can be considered a contemporary action of an ad vivum practice in the sense that it conveys a connection between the child selecting the source from life and using this as the basis of their authority. The practice is reminiscent of Panese's (2005) account of changes in Renaissance scientific drawings where Gessner inserted additions on pictures such as 'ad vivum expressus' (expressed from life). In this period such additions became a 'label of distinction and quality' (Panese, 2005, p. 71) serving to distinguish works via the acknowledgement of source. On reflection, it could also be the case that citing 'I looked at him/her' or 'I can tell be looking' function as a label of authority for assessing health. This observation points to the need for interpreting children's claims of looking as wielding an authority, perhaps far more than may have been previously acknowledged.

It is interesting that in many ways the children and young people in our study drew on a modern medical rationality described by Foucault; one that 'plunges into the marvelous density of perception, offering the grain of things as the first face of truth, with their colours, their spots, their hardness, their adherence' (1994, p. xiii). What is confounding is that while they deploy a clinical gaze, they do not produce clinically informed reports (for example, the conclusion that health is absence of fatness is inaccurate). They do not draw on clinical tools and devices, such as scales, nor do they delve below surfaces to the extent we might have expected. We are more likely to discover contemporary clinic-inspired depictions when they evaluate fat and food. When they speak of body fat, we are uncannily taken to an image of exteriors that are oddly more similar to those of Gessner's Renaissance marmot circa 1551 (and not of hBAT, circa 2010). 
This focus on looking, and more specifically looking from life, is dominated by visual and discursive assemblages (Deleuze \& Guattari, 1987) of health-obesity that include scientific discourses on obesity amongst a plethora of sources that give meaning to shapes, to movement to intake. These include schools, media, public health policies, peers and family (Burrows, Wright, \& McCormack, 2009; Wright, Burrows \& Rich, in press) as well as images of obesity that have a rich history (Gilman, 2010). Intake, for example, is subject to heightened censorship by schools (Welch, McMahon \& Wright, in press) that not only exerts controls on what children consume but influences what they take from life to mean health. The assemblage is one means for describing the culture from which the children and young people source their information about health. One of these influences on perceptions, the media, was evident in many of the responses, in both surveys and interviews. In the English interviews, for instance, participants were shown three media health headlines and asked which one stood out. In one interview two children chose 'Child Obesity has Doubled in Ten Years' and explained 'this was the more serious' (Female, 10 years, England). In another interview conducted in England, two students discussed a children's show that featured 'obesity',

\footnotetext{
R: $\quad$ On Blue Peter one of the presenters was obesity for a day and he described that it was really hard to be on the streets when people were looking at you and maybe when you go into shops it feels embarrassing to buy -

G: $\quad$ Clothes -

R: $\quad$ Big clothes and other people, some other people are maybe looking at you thinking ... (Female students, 8 years, England)
}

Reliance on media were at times troubling, with young people drawing on media representations for their knowledge even when they were engaging in a level of critique.

I don't think it's real fair to say that they're not real. Obviously in magazines, with all the airbrushing and stuff we perceive them to be pretty amazing, but as people, they're probably you know, quite healthy and good looking as such. (Female, 16 years, England).

Even with this critique of techniques such as 'airbrushing', the status of the non-obese who are viewed as thin, 'healthy and good looking' are the means to assess health.

Teachers in our study commented on the influence of the media and children's perceptions of health. This is evident in the quote below where a teacher describes one of her colleague's classroom activities,

Well J did a really interesting thing with her class; she got them to cut out things in magazines that they thought were healthy. And all of the kids cut out thin people; if you're not thin you're not healthy. (Female primary school teacher, New Zealand)

This description indicates the teacher's sensitivity to media representations as well as revealing how these aspects of contemporary visual culture are integrated into the classroom. Media representations were also influential on teachers, as one of the teacher respondents explained,

... the media certainly influences me a lot, there's no doubt about that. What I'm hearing on television and reading in the newspaper, you know, I certainly base a lot of what my feelings are on obesity on that. (Male primary school teacher, Australia) 
Reminiscent of the children and young people, teachers were also influenced by shape, making observations about children's shapes in a variety of ways. One comment by a primary school teacher stands out. This teacher made a comparison between current students and her former school. The former students were described as 'fine physical specimens' (Female primary school teacher, New Zealand), a choice of language and objectification that places young bodies squarely in the particular kind of gaze that is at once clinical but not the type of 'below surface clinic' that we might expect.

These examples of teachers' perceptions point to the ways visual and discursive assemblages of health-obesity are integrated in schools. Children and young people draw on these when they look from life to assess health. It is useful here to pause to consider how Gessner's ad vivum is interpreted. Kusukawa maintains that understanding Gessner's ad vivum demands appreciation of the visual culture of that period,

The lesson for us here is that images from the Historia animalium were part of a larger visual culture encompassing live, dried or partial specimens, drawings, prints and illustrated books, in which direct observation of the original was not yet a strict requirement for its images to be 'ad vivum' (2010, p. 322).

Looking, for Gessner, entailed surveying and collecting a variety of information on a range of creatures, a catalogue of truthful representations documenting descriptions of sea monsters, rabbits and marmots. This, however, is not the case with the findings from our study. Looking ad vivum by the children and young people supported the creation of impoverished tapestries to explain healthy bodies. It would be a mistake to grant these the status of truth in the same way that historians of science have assessed Gessner (Ashworth, 1996; Kusukawa, 2010). Rather, what might be more useful is to appreciate how the new health imperatives impact on children's and young people's assessments of healthy bodies. It is therefore crucial to recognise that reliance on looking ad vivum needs to be accounted for as an issue to recognise if health understandings are to be improved.

\section{Conclusion}

Children and young people report their truthful representations of visual and discursive culture when they look ad vivum. They take up certain information about fat and this enables them to look at health. When they do this they are reporting on understandings of health that pick up on what Gilman (2011) points out is a momentous visual attention to obesity. This is an important insight for grasping how a generation of children are now interpreting health in terms of looking ad vivum at the surfaces of fatness. These findings underscore the importance of recognising that when children and young people assess health they are producing understandings heavily orientated by ad vivum looking. Equating fat with health, together with the authority of looking, provides the rationality from which it is possible to look at shapes, at movement and at intake and be completely confident this will reveal health. This is also the means by which children and young people can include or exclude themselves and others as candidates of ill health. This in itself has significant implications for education initiatives that seek to prevent ill health. If we are not satisfied with these misunderstandings, the point is not to turn to correct the children, but rather, to dutifully consider how and from where they are assessing health, to 
critically examine how they are being taught to rely on looking and to act to rectify the misunderstandings that are created in the manner that this looking ad vivum is applied.

\section{Notes}

${ }^{1}$ All names and identifying information have been removed and replaced where necessary with pseudonyms or initials.

${ }^{2}$ So important was Gessner's identification of this structure that contemporary scientific discussions of BAT reference the discovery (Cannon \& Nedergaard, 2008; Enerbäck, 2010; Tews \& Wabitsch, 2011). Now termed as 'the good fat', BAT it is reported as a preventive for obesity in scientific journals (Chao, et al., 2011), with international newsprint media reporting it as a scientific breakthrough in the battle with obesity (Gray, 2009; Paddock, 2011; Wang, 2010). BAT even has its own Facebook page.

${ }^{3}$ Funded by ARC and ESRC Grants. ARC Linkage International Social Science Collaboration 20072010 The impact of attitudes and policies relating to obesity and related health issues on school policy and practices: J. Wright, V. Harwood, UOW, Australia; L. Burrows, University of Otago, New Zealand; E. Rich, \& J. Evans, Loughborough University, England.

${ }^{4}$ For reasons of space, social class, gender and ethnicity are not treated separately in this paper. In depth analysis of these subjectivities in terms of the ad vivum of students is the focus of a forthcoming essay. See Wright, Burrows and Rich (in press) in this special issue for discussion of class. For detail on fieldwork in England see Rich (2011).

${ }^{5}$ Surveys were with primary and secondary school students. Interviews were with teachers (including deputy principals, principals) and with primary and secondary school students. Number of interviews - Australia: 22 teacher interviews, 62 student interviews; England; New Zealand: 10 teacher interviews, 30 student interviews.

${ }^{6}$ These were questions 21, 22, 23 on the survey instrument developed for the English cohort. A different format of the survey instrument was used in Australia and New Zealand.

${ }^{7}$ This number is higher than the number of participants (1176) because subcategories allowed respondents to select more than one answer within each category. Numbers are indicative of frequency of response and allow comparison of the numbers of responses across possible answers.

${ }^{8}$ This creature inhabits alpine areas in Europe, including the mountainous areas in Switzerland in proximity to where Gessner lived and worked (Fischer, 1966).

${ }^{9}$ While reference to Gessner's discovery can be found in contemporary publications discussing brown adipose tissue (BAT) the marmot illustration in Historia Animalium has to my knowledge remained unpublished.

${ }^{10}$ One hundred years later the famous Histoire des animaux (Perrault, 1671) was based solely on direct observation and dissection (Guerrini, 2006). This book can be accessed online at http://www.archive.org/details/mmoirespourserv00bzgoog.

${ }^{11}$ The fifth was published posthumously, with the volumes.

${ }^{12}$ Volume $\mathrm{V}$ was published posthumously.

${ }^{13}$ An edited translation with additions was made into English by Edward Topsell in 1658, titled The history of four-footed beasts and serpents: describing at large their true and lively figure, their several names, conditions, kinds, virtues ... countries of their breed, their love and hatred to mankind, and the wonderful work, London: Printed by E. Cotes for G. Sawbridge, T. Williams, and T. Johnson.

${ }^{14}$ It is the case that illustrations were made of interior of humans and creatures prior to the eighteenth century, however these differ in many ways from latter scientific drawings, including style, naturalism and representation of object and subject (Hall, 1996).

${ }^{15}$ My thanks to the anonymous reviewer who pointed to the connections with lay epidemiology.

\section{References}

Andreotti, F., Rio, T., \& Lavorgna, A. (2009). Body fat and cardiovascular risk: Understanding the obesity paradox. European Heart Journal, 30(7), 752-754.

Ashworth, W.B. (1996). Emblematic natural history of the Renaissance. In N. Jardine, J.A. Secord, \& E.C. Spary (Eds.), The cultures of natural history (pp. 17-37). Cambridge: Cambridge 
University Press.

Bender, J., \& Marrinan, M. (2010). The culture of the diagram. Stanford: Stanford University Press.

Burrows, L. (2010). 'Kiwi kids are Weet-Bix ${ }^{\mathrm{TM}}$ kids'-Body matters in childhood. Sport, Education and Society, 15(2), 235-251.

Burrows, L., Wright, J., \& McCormack, J. (2009). Dosing up on food and physical activity: New Zealand children's ideas about 'health'. Health Education Journal, 68(3), 157-169.

Cambrosio, A., Keating, P., Schlich, T., \& Weisz, G. (2009). Biomedical conventions and regulatory objectivity: A few introductory remarks. Social Studies of Science, 39(5), 651-664.

Cannon, B., \& Nedergaard, J. (2008). Developmental biology: Neither fat nor flesh. Nature, 454, 947948.

Chao, P.-T., Yang, L., Aja, S., Moran, T.H., \& Bi, S. (2011). Knockdown of NPY expression in the dorsomedial hypothalamus promotes development of brown adipocytes and prevents diet induced obesity. Cell Metabolism, 13(5), 573-583.

Davison, C., Smith, G.D., \& Frankel, S. (1991). Lay epidemiology and the prevention paradox: The implications of coronary candidacy for health education. Sociology of Health and Illness, 13(1), 1-19.

Deleuze, G., \& Guattari, F. (1987). A thousand plateaus: Capitalism and schizophrenia (B. Massumi, Trans.). London: University of Minnesota Press.

Enerbäck, S. (2010). Human brown adipose tissue. Cell metabolism, 11(4), 248-252.

Fischer, H. (1966). Conrad Gessner (1516-1565) as bibliographer and encyclopedist. The library, XXI(4), 269-281.

Foucault, M. (1994). The birth of the clinic: An archaeology of medical perception. New York: Vintage.

Foucault, M. (2006). History of madness (J. Murphy \& J. Khalfa, Trans.). Abingdon, Oxon: Routledge.

Frankel, S., Davison, C., \& Smith, G.D. (1991). Lay epidemiology and the rationality of responses to health education. The British Journal of General Practice, 41(351), 428-430.

Gessner, C. (1551). Historia animalium lib. I. Tiguri: Apvd Christ. Froschovervm.

Gilman, S.L. (2010). Obesity, the biography. Oxford: Oxford University Press.

Gilman, S.L. (2011). Representing health and illness: Thoughts for the 21 st century. Journal of Medical Humanities, 32(2), 69-75.

Gracia-Arnaiz, M. (2010). Fat bodies and thin bodies. Cultural, biomedical and market discourses on obesity. Appetite, 55(2), 219-225.

Gray, R. (2009, 25 August). Obesity: Why fat itself may be the answer: Reprograming body fat is the key to weight loss, not working out says Richard Gray. The Daily Telegraph. Retrieved 23 August, 2012 from http://www.telegraph.co.uk/science/6083234/Health-warning-exercisemakes-you-fat.html.

Guerrini, A. (2006). The 'virtual menagerie': The histoire des animaux project. Configurations, 14(12), $29-41$.

Hall, B.S. (1996). The didactic and the elegant: Some thoughts on scientific and technological illustrations in the middle ages and renaissance. In B.S. Baigre (Ed.), Picturing knowledge. Historical and philosophical problems concerning the use of art in science (pp. 3-39). Toronto: University of Toronto.

Harwood, V. (2011). Connecting the dots: Threat assessment, depression and the troubled student. Curriculum Inquiry, 41(5), 586-609. 
Johns Hopkins Medical Institutions. (2011, May 5). Turning 'bad' fat into 'good': A future treatment for obesity? Science Daily. Retrieved 25 October 2011 from http://www.sciencedaily.com/releases/2011/05/110503132704.htm

Klein, R. (2010). What is health and how do you get it? In J. Metzl, M. \& A. Kirkland (Eds.), Against health: How health became the new morality (pp. 15-25). New York: New York University Press.

Kusukawa, S. (2010). The sources of Gessner's pictures for Historia animalium. Annals of Science, 67(3), 303-328.

Le Besco, K. (2010). Fat panic and the new morality. In J.M. Metzl, \& A. Kirkland (Eds.), Against health: How health became the new morality. New York: New York University Press.

Paddock, C. (2011). How to burn calories instead of storing them: Turn bad fat into good fat? Medical News Today. Retrieved 28 October 2011 from http://www.medicalnewstoday.com/articles/224183.php

Panese, F. (2005). The accursed part of scientfic iconography (D. Thomas, Trans.). In L. Pauwels (Ed.), Visual cultures of science: Rethinking representational practices in knowledge building and science communication (pp. 63-89). Hanover: Dartmouth College Press.

Perrault, C. (Ed.). (1671). Mémoires pour servir à l'histoire naturelle des animaux, 2 vols. Paris: Imprimerie royale.

Pinon, L. (2005). Conrad Gessner and the historical depth of Renaisance natural history. In G. Pomata, \& N.G. Siraisi (Eds.), Historia: Empiricism and erudition in early Modern Europe (pp. 241268). Massachusetts: MIT Press.

Rabinow, P. (1992). Studies in the anthropology of reason. Anthropology Today, 8(5), 7-10.

Rich, E. (2011). Exploring the relationship between pedagogy and physical cultural studies: The case of new health imperatives in schools. Sociology of Sport Journal, 28(1), 64-84.

Rich, E. \& Evans, J. (2009). The impact of the new health imperatives in schools: Full research report ESRC End of Award Report, RES-000-22-2003. Swindon: ESRC.

Rutkowski, J., Davis, K.E., \& Schere, P.E. (2009). Mechanisms of obesity and related pathologies: The macro- and microcirculation of adipose tissue. FEBS Journal, 276(20), 5738-5746.

Speake, J. (Ed.). (1999). The Oxford Essential Dictionary of Foreign Terms in English Oxford: Oxford University Press.

Tan, D.X., Manchester, L.C., Fuentes-Broto, L., Parades, S.D., \& Reiter, R.J. (2010). Significance and application of melatonin in the regulation of brown adipose tissue metabolism: Relation to human obesity. Obesity Reviews, 12(3), 167-188.

Tews, D., \& Wabitsch, M. (2011). Renaissance of brown adipose tissue. Hormone research in paediatrics, 75, 231-239.

Wang, S.S. (Producer). (2010, 6 April, 2011) A new way to lose weight? Scientists see the potential in the calorie-burning value of 'good' fat in adults. The Wall Street Journal Online. Retrieved July 202011 from http://online.wsj.com/article/SB10001424052702304506904575180053884870776.html

Welch, R. McMahon, S, \& Wright, J (2012). The medicalisation of food pedagogies in primary schools and popular culture: A case for awakening subjugated knowledges. Discourse: Studies in the cultural politics of Education, 33(5).

Wright, J., Burrows, L., \& Rich, E. (in press). Health imperatives in primary schools across three countries: Intersections of class, culture and subjectivity. Discourse: Studies in the Cultural Politics of Education. 
